\title{
Witchcraft Accusation and Church Discipline in Malawi
}

\author{
Timothy Kabulunga Nyasulu
}

My area of concern in commenting on the work that has been done by Robert Priest, Abel Ngolo and Timothy Stabell (2020) in Democratic Republic of Congo (DRC) Kinshasa is on church discipline practice that deals with witchcraft issues in the Church of Central Africa Presbyterian (Synod of Livingstonia). This is mainly in connection with my PhD research that I conducted in 2010 at Trinity International University.

Many surveys and researches have been conducted in many African countries on child witchcraft accusations and have shown that thousands of people including children are accused of practicing witchcraft. Studies in child-witch accusations have shown that some children have been physically abused and thrown out of their homes and killed over the last years. Scholars like Erwin Van Der Merr ${ }^{1}$ have written that many such accused children are vulnerable; some are orphans whose parents died of HIV and Aids, some are disabled, while others are from very poor families. Unfortunately in most of these African countries the archaic Witchcraft Act does not protect the vulnerable in society and is often misapplied to secure convictions.

Hate, cruelty and abuse against children are rampant in these countries including Malawi (Chilimampunga 2012, 61). When assessing child witchcraft accusations, Erwin Van Der Merr noted that the findings of their research in Southern Malawi are similar to those found in Akwa Ibom state in Nigeria, Angola, Democratic Republic of Congo, but with less hatred being expressed towards children who are believed to be witches. In these countries socioeconomic problems, rapid urbanization, the impact of HIV/AIDS pandemic and the influence of some Nigerian religious movies are some of the factors that cause children to be accused of witchcraft. In Malawi while many see the children at least partly as victims who have been misled by elderly people who are believed to have taught them witchcraft, some still think the children are really evil and need to be punished even by execution. In most Pentecostal evangelical churches they employ prayers to exorcise the witchcraft spirit from them (Munyenyembe 2012, 37).

Commenting on the situation in DRC where Robert Priest et al. did their survey, child witchcraft accusation is usually by parents or guardians who are accusing their children or dependents (4). According to Priest's analysis such accusations are emanating from interpersonal causal ontologies in which, instead of asking the question why and what, they ask "who". The fact that parents, guardians and even neighbors are perpetrators of witchcraft accusations against children makes it hard to campaign against it. It is difficult even in the church.

In northern Malawi in the days of early Scottish missionaries when church discipline was being introduced, parents of children who were being accused of practicing witchcraft also faced moral disciplinary charges because they were considered to have failed to bring up their children well as Christian parents. ${ }^{2}$ Reports would come to church that parents whose children were accused of witchcraft went to consult witchdoctors to find out if indeed their children were witches, and they would be summoned to appear before the discipline committee of the church, and later to the Kirk Session for suspension from Holy Communion and other leadership roles in the church. If the DRC case were happening in Malawi, and if the child's father was in the same Protestant church where

\footnotetext{
' Revelations presented by Erwin Van Der Merr's survey which was conducted in 2013 on Child Witchcraft Accusations in Southern Malawi are very helpful. His work has revealed that accusations do not only accuse and affect children who are vulnerable but also the poor and illiterate elders who spend time accusing others in that family.

2 The late Very Rev Dr Silas Nyirenda, former lecturer used to inform us in Synodical Instructions at Zomba Theological College that in the early days of missionaries Church discipline was a very serious issue. It was making sure that all parents grow their children in all forms of good morals. Those that failed to do so they were summoned by the church to reprimand and discipline them.
} 
the child was a choir member the father would be summoned to appear before the church court facing disciplinary charges. Ironically and contradictorily if parents did not go to consult diviners yet their children were being accused, they would be considered by the community to be supporting their children and even suspected of having taught their children witchcraft.

Like in many African countries, witchcraft accusations in Malawi are associated with economic struggles people have in their homes and families. In my doctoral research conducted in 2010, it was found that on average four percent (4\% percent) of the discipline cases in congregations have to do with divinations. ${ }^{3}$ At every monthly Kirk Session, reports on how people are implicated in witchcraft related stories whether as accusers or accused are submitted (Nyasulu 2010, 46). Among these cases are those to do with child witchcraft accusations. Although I am unable to say the exact percentage, child witchcraft accusation are very minimal compared to those against the elderly. However discouraging the perpetration of witchcraft accusations in church among church members can be regarded as the main active role the church is playing to deal with witchcraft. The church even disciplines those that have been involved or are implicated in the scene especially by consulting diviners or those involved in a dance related to spirit possession which is believed to have some witchcraft elements. ${ }^{4}$ In its attempts to discourage the belief in witchcraft the church disciplines those that either have gone for divination or accuse others of witchcraft by suspending them from taking Holy Communion for a period of time. Sometimes if there is evidence that one is indeed a witch depending on the accepted evidence, such people are also exempted from taking Holy Communion for some time until they repent that they will no longer be involved in such acts.
It was interesting to find that the highest rate of divination and witchcraft accusations are in the rural congregations; about six percent $(6 \%)$ compared to the urban congregations where it is about two to three percent $(2-3 \%)$. Some of the interviewees ascribed this scenario to the fact that in the rural areas or countrysides most people are illiterate and uncivilized so they are more into witchcraft beliefs than those in the urban areas where people might have a better education. Also in the rural areas there are more economic challenges compared to the urban areas because most people are not employed. Some analysts have argued that witchcraft accusation is a form of denial that families have chosen rather than accepting that they are responsible for their own socio-economic hardship.

It was also found that many old women and men were staying with their grandchildren who were orphans and whose parents died of HIV/AIDS, and it was found that the elderly in their poor state were accused more than the young ones. Also the number of old women exceeded the number of old men ${ }^{5}$. Unfortunately it was found out that very little pastoral care is given to the people to understand them well and to find a better solution to the problem in the church. ${ }^{6}$ In the table below readers will find witchcraft accusations dynamics. The word used is divination where people are reported to have consulted diviners on witchcraft accusations. It should be known that the Church of Central Africa Presbyterian (CCAP) church does not want to encourage people to believe in witchcraft. Its approach to deal with witchcraft is that it discourages the belief in witchcraft; therefore church members should not try to find out whether someone is bewitched. It is those who claim to know if someone has been bewitched or not that are encouraging the belief in witchcraft among people. So whether the accused is a child or an elderly person the church approach is the same. This is said to have originated during the time of the early

\footnotetext{
${ }^{3}$ Read PhD Dissertation by Timothy Nyasulu. 2010. Bringing the Sheep back to the Carroll: A Moral Discipline in the Church on Central Africa Presbyterian (CCAP) Synod of Livingstonia 1995-2005, 163.

\begin{abstract}
${ }^{4}$ What was common among Livingstonia missionaries and those elsewhere on this issue was that converts involved in spirit possession ceremonies were excluded from church membership. In Malawi converts found guilty of spirit possession were suspended for a period of nine months. The reason behind this was that spirit possession is much related to divination. Dancing and spirit possession was to harness powers from the spirits. Read Silas Ncozana, 2002, The Spirit Dimension in African Christianity: A Pastoral study among the Tumbuka of the Northern Malawi, pp.188-189.
\end{abstract}

${ }^{5}$ A story was shared at an Annual General Meeting of the Public Affairs Committee on $19^{\text {th }}$ December 2019 by the Catholic Bishop of Karonga Diocese that in a certain district in the northern region grandchildren accused their grandmother of having bewitched one of her grandsons. Youths and the grandsons got angry and they killed the old women through mob justice. Interestingly he associated this to ignorance and poverty among people including the youths. He lamented that most of such people that are accusing others for practicing witchcraft are in a poor state. He advised in his lament that the only way to deal with witchcraft accusations is to send the young people to school. He beliefs that education will end witchcraft beliefs and accusations little by little.

${ }^{6}$ Read PhD dissertation by Timothy Nyasulu. 2010. Bringing the Sheep back to the Carroll: Moral Discipline in the Church of Central Africa Presbyterian (CCAP) Synod of Livingstonia 1995-2005, p. 167. 
missionaries. When they found that Africans had strong beliefs in witchcraft and would spend time inquiring about it from diviners, they discouraged and banned the consultation of diviners. Walter Trobisch who worked in Africa many years observed that the punishment that is given to offenders in the African church is not because the punishment was introduced by the missionaries. It was because missionaries already saw in African leadership that heavy punishment was already part and parcel of tradition. Therefore introducing a system of punishing those that have offended or broken the moral laws was already normal and would not make a great change. Any person found to be involved in witchcraft would be summoned for discipline and suspension would follow. Table One below provides the discipline cases that are handled by the CCAP church. In it readers will find the percentage of divination cases, for which people face disciplinary charges for consulting diviners who are believed to promote witchcraft beliefs.

\section{Table 1: Reasons for Church Discipline}

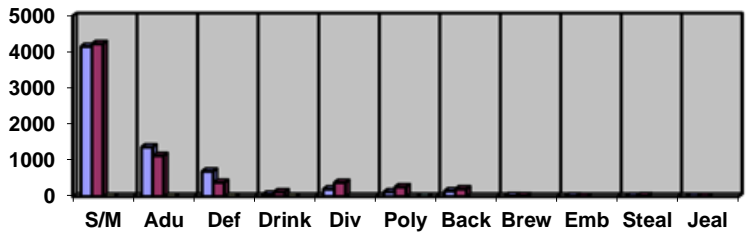

$\underline{\text { Key }}$

- $\quad \mathrm{S} / \mathrm{M}$ stands for self marriage. People who have married outside the church.

- Adu stands for adultery.

- Def stands for defection. Those who have abandoned the CCAP church for whatever reason. They are regarded as having defected, or changed their faith.

- $\quad$ Drink stands for beer drinking.

- Div stands for divination. This is the subject of witchcraft accusation and church discipline that is discussed in this paper.

- Poly stands for polygamy.

- Back stands for backsliding, those that have left off going to church.
- Brew stands for brewing beer. Those that brew beer are also suspected because they are believed to be promoting the sin of beer drinking.

- $\quad$ Emb stands for embezzlement of church funds.

- Jeal stands for jealousy.

NB: The numbers to the left (0-5000) represent the number of church members in the congregations in which I conducted research. The red colour represent urban congregation and the blue colour represent the rural congregations

Table 2: Rural vs. Urban Comparison of Reasons for Church Discipline

\begin{tabular}{|l|r|r|l|r|r|}
\hline FOUR RURAL SESSIONS & \multicolumn{3}{|l|}{ FOUR URBAN SESSIONS } \\
\hline Offense & Number & $\begin{array}{c}\text { Percent } \\
\text { of Total }\end{array}$ & Offense & Number & $\begin{array}{c}\text { Percent } \\
\text { of Total }\end{array}$ \\
\hline S-Marriage & 4,223 & $62 \%$ & S-Marriage & 4,147 & $61 \%$ \\
\hline Adultery & 1,135 & $17 \%$ & Adultery & 1,376 & $20 \%$ \\
\hline Defection & 391 & $6 \%$ & Defection & 702 & $10 \%$ \\
\hline Drinking & 125 & $2 \%$ & Drinking & 61 & $0.9 \%$ \\
\hline $\begin{array}{l}\text { Divination/witch- } \\
\text { craft accusation }\end{array}$ & 388 & $6 \%$ & Divination & 207 & $4 \%$ \\
\hline Polygamy & 265 & $4 \%$ & Polygamy & 129 & $2 \%$ \\
\hline Backsliding & 210 & $3 \%$ & Backsliding & 154 & $2.3 \%$ \\
\hline Brewery & 17 & $0.3 \%$ & Brewery & 19 & $0.3 \%$ \\
\hline Embezzle & 2 & $0.03 \%$ & Embezzle & 11 & $0.2 \%$ \\
\hline Stealing & 15 & $0.2 \%$ & Stealing & 9 & $0.1 \%$ \\
\hline Jealous & 4 & $0.05 \%$ & Jealous & 2 & $0.03 \%$ \\
\hline Total & 6,775 & $100 \%$ & Total & 6,817 & $100 \%$ \\
\hline
\end{tabular}

In the table, $4 \%$ of divination cases are in the urban and $6 \%$ divination cases are in the rural areas. According to respondents, ${ }^{7}$ people in the rural areas are less civilized, poor and illiterate. In the urban areas the majority is employed or does some business. They are civilized, literate and better able to find something to support themselves. Some respondents during interviews expressed their observations and opinion that what causes such accusations is that people in the rural places are envious and jealous about what other prosperous people are doing.

Although on a very small scale, CCAP pastors also conduct deliverance sessions for children accused of witchcraft during what is called "contemporary services". ${ }^{8}$ Pentecostal churches are more open and conduct their deliverance sessions in a very open and transparent manner. ${ }^{9}$ They are different from the

\footnotetext{
The research that I conducted in 2009 on church discipline in the CCAP Synod of Livingstonia included participants from both rural and urban areas. It was interesting that they pretty well knew that there is a difference between those staying in town and those in the country side. Those staying in town are more literate and well to do people. However the difference is very minimal indicating that even those that are found in town still live a village life because of their strong belief in witchcraft. It was also shared that some people in town can invite diviners to assist them, or bring witchcraft missiles to town so that they protect themselves from witches.
}

${ }^{8}$ The mainline churches including the CCAP have for the past two decades faced the challenge of losing young generations from church services. There has been a huge exodus of many youths, leaving the mainline churches in pursuit of the deliverance prayers and lively worship services in the Pentecostal churches. To keep the young people in church, the CCAP Synod of Livingstonia has introduced what is known as "contemporary services" which address issues of freedom of expressions of people's faith, attending to prayer needs that have are submitted during worship services such as those who would like to be prayed for because of diseases, witchcraft, prosperity matters, etc.

${ }^{9}$ There are still some CCAP pastors that hold their deliverance prayers in secret. 
mainline churches like CCAP and the Anglican Church. The Pentecostals openly preach and teach that indeed witchcraft exists and can be dealt with through deliverance by prayers as witchcraft powers are believed to be demons. ${ }^{10}$ People accused of witchcraft including children are brought before those known as prayers warriors. ${ }^{11}$

A point of interest in the Priest et al. article is the link of witchcraft to the Christian concept of sin. The employment of prayers of exorcism over the accused by church people is meant to remove evil spirits or demons in child witches. Like in many other countries in Malawi, the accused children are demonized (Hackett 2003, 23). However like in Kinshasa it is noted that such children are coming from illiterate and poor families, are orphans, vulnerable, street kids etc. One wonders the accuracy or the truth of whether sin is associated with poverty or illiteracy. The prosperity gospel preachers take it as spiritual warfare from which an individual and family must be liberated. They will cast out demons from the children to cleanse the family of witchcraft and even force them to accept that they are witches. However in the context of the socio-political and socio-economic statuses, does this behavior not mean that the sin is not really in the accused but rather in the weak, powerless and vulnerable situation of the accused? To that effect there have generally been two responses to witchcraft so far noted: the modernist response and the Pentecostal response. The CCAP response is that of western missionaries which discourages the belief in witchcraft. Whoever is found perpetrating ideas that will make people believe in or promote witchcraft beliefs is taken to task. This is where church discipline is coming in. Such an approach is not pleasing to many Malawians. This approach also brings in what Clark might call "syncretism" (Clark 2001, 7) among church members because while the CCAP Church discourages its members to believe in witchcraft yet they know that witchcraft exists, they have a double standard form of exercising their belief. Kok has described this situation as living two realities of different kinds which does not give a clear picture of what Christianity really is (Kok 2005, 22). However still, in discouraging people to go for divination one can see some reduction of witchcraft accusations because people fear they might be suspended from Holy Communion if they are found to be perpetrating witchcraft matters.

Those that have chosen the Pentecostal response do attract many people's attention. However the challenge is to believe their approach to dealing with witchcraft. One can find African pastors, bishops, prophets, or apostles who do exactly what the diviners did before Christianity came. By means of supernatural revelation, they allegedly diagnose illnesses including spiritual afflictions and curses and reveal hidden sins. ${ }^{12}$ Some scholars have referred to this as "Christian" witch hunting, including torture (Bourdillon 2002, 11). If people prayed for have been known they are given names in their respective homes. ${ }^{13}$ They are isolated and treated as demonic. Some "prophets" have publicly accused people of witchcraft without any evidence (Hoskins 2004, 59). This is a powerful means of social control which instills fear in church members and keeps them behaving well, but often degenerates into psychological or other forms of abuse (Hoskins 2004, 5). Such an approach has taken supernatural evil very seriously without being careful to follow what scripture says. Paul Hiebert clearly cautions against this. He states that while taking supernatural evil seriously, we must also guard against Christianity itself being adapted into a new form of magic (Hiebert and Meneses 1995, 172ff). He also cautions that ironically both the modernist and magical (Pentecostal) approaches reflect a mechanistic worldview-a formula approach to reality that allows humans to control their own destiny-the modernist based upon scientific formulas of cause-andeffect in accordance with natural laws, and the magical based upon a spiritual formula in accordance with presumed spirits' activities.

Another interesting point raised by Priest that might be of interest in these witchcraft accusations is the confusion and different understandings of the use of language. How a term is used can be different from one place to another. For instance, how Americans use the word football is different from the rest of the world. Priest writes on pages 5 and 6 that while English speakers will sometimes assume that there is a single

\footnotetext{
${ }^{10}$ Rhodian Munyenyembe in his book explains how people believed to be witches are taken to Pentecostal pastors for deliverance. Some Pentecostal churches have evening sessions where they do nothing else but to pray for people that have come for different reasons. One pastor who left the CCAP church some four years ago, has a big following in his church because he has made every Thursday the day to receive prayer requests and family complaints.

"Prayer warriors refer to those people that are gifted to pray prayers that heal the sick, to conduct deliverance prayers etc.

${ }^{12}$ For more information please read Ulf Strohbehn 2005. Pentecostalism in Malawi: A History of Apostolic Faith Mission in Malawi. Zomba Kachere, pp. 55-56.

${ }^{13}$ These names are for mockery. For instance, someone can be nicknamed "chimalawanthu", a person who has finished all people in the village because of his/her witchcraft.
} 
clear meaning to the term "witch" or "witchcraft," in fact the word "witch" can confuse people in conversation when the partners have completely different referents in mind.

In Malawi the term "witch" (mfiti in Chichewa and Fwiti in Chitumbuka) is most commonly used as a generic term for all those that inflict pain, tragedy, suffering, and even kill. The word "Ng'anga" which is similar to Baganga in Swahili can be interpreted differently. When one says he is ng'anga or mganga it simply means someone who helps to remove the evil powers in a witch by evoking what is the cause of the sickness of a person. Such a person can provide medicine for healing or can just tell what the cause of the problem is. The word sing'anga has also brought some confusion and misunderstanding. While it can be interchangeably used with ng'anga, the specific meaning of each is slightly different. Si-ng'anga is the opposite of ng'anga. In Chichewa language when one uses "si", it means "not". Therefore the use of the prefix "si" gives a connotation that he/she is not doing the work of "ng'anga". So if a person is a sing'anga then he or she is close to a witch. He is a diviner. Some would refer to such a person as witchdoctor. He or she deals with those who are witches. While there is some positive connotation, the question that is regularly asked is how is she/she able to deal with the witch/witchcraft? Therefore that person should know about witchcraft. Unless you are a witch, you cannot know witchcraft. However when people converse they understand each other whether they use the word positively or negatively.

This might possibly be the reason why those going for witchcraft consultation, whether positively or negatively, are put under discipline. In such communities consulting ng'anga or sing'anga on witchcraft issues is considered to create a situation and perception that indeed witchcraft exists which is believed to be evil.

\section{Way Forward: Redefining the Role of the Church on Witchcraft Accusations}

The church needs to look back and see how it has served its people especially those involved and implicated in witchcraft accusations. The church should be concerned with the vulnerable in its community. The accused are victimized. They have no voice. Innocent children can suffer accusations and even lose their lives. Elderly people who are sources of wisdom in society are forced to die for no good reason. What should the church do?

\section{God is more powerful than all the powers in the world.}

From the outset we should mention that lack of a well-developed biblical approach towards reaching those Malawians who practice and believe in witchcraft and magic has crippled the growth of the church. Understanding some of the reasons why people practice magic and witchcraft will unearth issues not known by many church leaders and offer solutions to the problems. People should know the word of God as regards to the power that He has over the universe. Yes, people's beliefs must be taken seriously even if they can be wrong. It is a fact and clear in most African contexts that if there is anything that people live with it is the fear of witchcraft attacks (Ashforth 2005, 88). As such, witchcraft beliefs cannot be taken lightly.

The church today should take a different approach than that of the missionaries who just condemned the beliefs without careful study. The fact that God ruthlessly condemns the belief and practice of magic (Exod.9:11); witchcraft (1 Sam.15:23); divination (Deut. 18:10); fetishes (Exod. 20:3-6); and shamanism (Lev. 20:6) practiced by the tribes surrounding Israel (Hiebert and Meneses 1995, 173), does not mean that we can let it go without proper teaching to church members. We need to go beyond the mere condemning of the belief. God is above all that is happening in the world. The church should proclaim that God is more powerful than all spirits, real and imagined, and that he delivers his people from fear of them. The church should pray for those who are sick, possessed, fearful, and insecure and help them find refuge in the God of the Bible. God himself made it clear that all other gods are no gods (Exod. 32:19-20; Isa. 44:6-20).

\section{Protect the people of God.}

All people including children are created in the image of God. The church must openly love, embrace and protect people of all kind because redemption of their souls is precious. Jesus Christ did not choose between people. He embraced everybody including sinners. He, for good reason, even identified himself with the poor and the suffering. The church needs people. These are the people that need to be reached with the Gospel. The church is full of children and women. The population of the elderly is declining. If these people are abused and killed something must be wrong with the church which is supposed to be the voice of the voiceless. As such the protection of all these is not a choice but a must. Churches can write a pastoral letter condemning witch accusations in society and emphasize the power of God over witchcraft. This can be openly read in their churches on Sunday. In protecting people the Church must address witchcraft related issues. Secular organizations are more active in dealing with witchcraft issues than the church. This is unfortunate. The secular organizations have no Gospel. The good news is with the Church. The Church must 
address witchcraft in the larger non-Christian community of which it is part. It must defend Christians and others falsely accused of practicing witchcraft. It must also demonstrate the power of God to deliver when real witchcraft is involved (Hiebert and Meneses 1995, 175). Indeed witchcraft is a social evil that involves human beings, our church members, and indeed involves people who are part of God's creation; the Kingdom of light. If it is left to secular organizations the whole issue will be secularized. If it is unaddressed it brings chaos and discomfort among civil societies and church members, subsequently the church fails to witness to the Gospel of Christ to people and leaves the weak more vulnerable. When the church is quiet it supports evil. It is not playing its prophetic role. It doesn't have the voice of the voiceless. This is how witchcraft accusations came to an end in Europe and North America. In some countries like Angola efforts are made even to shut down witch hunting operation by Christian churches, citing gross human rights violations operations by Christian churches.

\section{Educate the people about their life development.}

How do we know that so and so has bewitched so and so? In Proverbs 19:2 it is written it is not good to have zeal without knowledge. Recently in Malawi for several times the Civil Society, the Law Society, and the Society of Secular Humanism have called for civic education against witchcraft accusations and condemned the brutal killings of the elders in many parts of the country. They came out strong when four elderly people were killed by youths in Mwanza because they were suspected of having bewitched a girl who was killed by lightening. It was alleged that the elderly had sent lightening to kill their granddaughter. Education is power it is said. Although some Malawians like to say money is power, money without good education can be useless and meaningless. As such the church should be advocating for good education among its people. In the case study of church discipline conducted by Nyasulu it was noted that belief in witchcraft and witch accusations are more common in rural areas among the less educated people than in urban areas among the more educated people. One would be right to argue that education is essential to most social, economic, and psychological issues in life. It is good that all along the Presbyterian Livingstonia Mission has believed education to be the key to all good things to which one would aspire in life; for them "it was not the wearing of the cross that marked change" (Ncozana 2002, 121). Rather "the school was a symbol of change and an effective means of proselytism. It was also thought to be like an exorcism against spirit beliefs. To some people it was also a means of getting rid of the fears of witchcraft" (Ncozana 2002, 121). It was once said by one of the believers, "To those of us who believe that education will be at least a factor in reducing this bondage of evil spirits, if only by degrees, progress in educational facilities must be of great interest" (Debenham, 1955, 171). This is not education in other subjects, but in theological studies which prepare people for the holy ministry. Apparently somewhere, somehow, a thread has been cut. There is very little emphasis, if there is any, in theological seminaries on witchcraft and the Church. The Church should encourage the teachers in theological seminaries to have this subject in their schools. The church should also teach people responsibility, stewardship, and hard work in life. People tend to avoid talking about issues like poverty, laziness, ignorance, diseases, failure to take care of the environment, etc., and finding ways of dealing with these problems. Instead, they spend time thinking about others.

\section{Render service to both the accuser and the accused.}

True religion that God accepts is that one takes care of the vulnerable, orphans, widows and the marginalized (James 1:27). As salt of the earth, the church has to embrace people and serve them. Both the accuser and the accused need help from the church. The accuser is supposed to know that witchcraft accusations do not provide answers to problems the society faces. In the case study above, jealousy and envy played a role in the killing of the four senior citizens. They hated the elderly living on among them because they cultivated a land which the grandchildren envied. People of this kind need serious counseling that will make them understand their evil behavior and accept Christ as their Savior and master of their life. As such they should be told categorically that whether witchcraft exists or not, what is important to know is that the power of God is sovereign and above all powers. The powers of darkness have been conquered by the power of Jesus. A practical holistic action to include service rendered to those caught up in the webs of fear, suspicion, and accusations associated with belief in witches must be taken. The accused people need to be cared for. They need not only to be received but also supported. The accused may be living in fear for their lives. The church must have a listening and examining ear before they believe a person.

\section{Bibliography}

Bourdillon, Michael. 2002. The Significance of Witchcraft in the Training of Clergy. Chiedza, Arrupe College Journal $5(2): 10-15$. 
Chilimampunga, Charles. 2012. The Extent and Nature of Witchcraft-Based Violence against Children, Women and the Elderly in Malawi. Chancellor College: University of Malawi. Zomba.

Clark, Matthew S. 2001. The Challenge of Contextualization and Syncretism to Pentecostal Theology and Missions in Africa. Journal of Asian Mission 3(1):79-99.

Hackett, Rosalind. 2003. Discourses of Demonization in Africa and Beyond. Diogenes 50(3):61-75.

Hiebert, Paul G and Meneses, Eloise. 1995. Incarnational Ministry: Planting Churches in Band, Tribal, Peasant and Urban Societies. Grand Rapids, MI: Bakers Books.

Hoskins, Richard. 2004. Africa Independent Churches. In New Religions: A Guide: New Religious Movements, Sects and Alternative Spiritualities. Christopher Partridge, ed. Pp. 48-60. New York: Oxford.

Kok, Bregje de. 2005. Christianity and Africa Traditional Religion: Two realities of a different kind: $A$ cultural psychological study of the way Christian Malawian account for their involvement in African Traditional Religion. Zomba, Malawi: Kachere Series.

Munyenyembe, Rhodian. 2012. Christianity and Social Cultural Issues: The Charismatic Movement and Contextualization. Kachere Thesis No. 19. Mzuni Books No. 3.

Ncozana, Silas. 2002. The Spirit Dimension of African Christianity: A Pastoral Study of the Tumbuka People of the Northern Malawi. Kachere Monograph. Blantyre: CLAIM.

Nyasulu, Timothy K. 2010. Bringing the sheep the Corral: Moral Discipline in the Church of Central Africa Presbyterian (CCAP), Synod of Livingstonia 1995-2000. $\mathrm{PhD}$ dissertation submitted to Trinity International University.

Priest, Robert J., Abel Ngolo and Timothy Stabell. 2020. Christian Pastors and Alleged Child Witches in Kinshasa, DRC. On Knowing Humanity Journal 4(1):1-51.

Trobisch, Walter. 1961. Church discipline in Africa. Practical Anthropology 8:200-207.

Van der Meer, Erwin. 2009. The Spiritual Warfare Theology of C. Peter Wagner and its Implications for Christian Mission in Malawi. Thesis submitted for a DTh degree. Pretoria: UNISA.

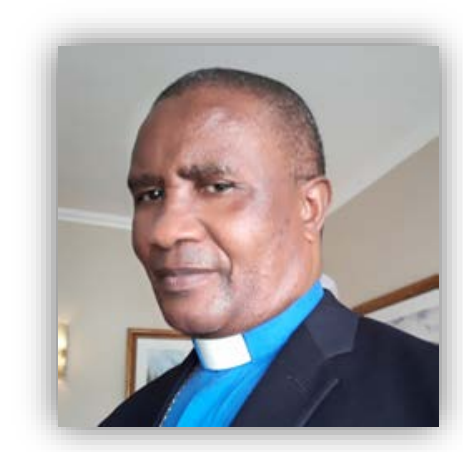

Rt. Rev Timothy Kabulunga Nyasulu, PhD, is the Vice Chancellor of the University of Livingstonia. He is the current Moderator of the CCAP General Assembly (Livingstonia, Blantyre, Nkhoma, Harare and Zambia Synods). He has served in both rural and urban congregations within the CCAP Synod of Livingstonia. He has headed synod departments as Director including the Lay Training Centre and Education Departments. He was the first Regional Coordinator of Theological Education by Extension in Malawi (North). He has taught for many years and held positions in institutions of higher learning. He has served in many government and non governments boards of directors.

Author email: nyasulutpk1962@gmail.com 